\title{
Horizontal sedimentation differences in a eutrophic Swiss lake
}

\author{
Jürg Bloesch and Urs Uehlinger
}

Institute of Aquatic Sciences (EAWAG), Swiss Federal Institute of Technology (ETH), Ueberlandstrasse 133, CH-8600 Dübendorf, Switzerland

\begin{abstract}
Settling fluxes measured by means of scdiment traps were $887 \mathrm{~g}_{\text {dry }} \mathrm{wt} \mathrm{m}^{-2} \mathrm{yr}^{-1}, 113 \mathrm{~g} \mathrm{POC}$ $\mathrm{m}^{-2} \mathrm{yr}^{-1}$, and $2.6 \mathrm{~g} \mathrm{PP} \mathrm{m}^{-2} \mathrm{yr}^{-1}$ in 1982-1983 at a central station in eutrophic Lake Hallwil, Switzerland. Nearshore scttling rates were higher by a factor of 1.4-3.4. Since particulate organic carbon (POC), particulate phosphorus (PP), and biomass concentration in the lake water showed vertical rather than horizontal differences, this result was attributed to permanent bottom sediment resuspension and redeposition in the littoral zone. Horizontal sediment transport (sediment focusing) and sediment resuspension in the profundal zone in winter, when wind and turbulence are increased, accounted for only about $20 \%$ of the sedimentation rates. Because $70-80 \%$ of the total sedimentation for the year occurred during summer, such processes are of minor importance in Lake Hallwil, although a "nepheloid" layer with increased POC and PP concentrations 5-8 m above the bottom was present. It is stressed that the mechanisms of sediment transport must be known to permit interpretation of trap results and to understand lake metabolism.
\end{abstract}

Sedimentation is one of the fundamental processes governing lake metabolism by influencing epilimnetic nutrient regeneration, removing particulate matter to the bottom, and controlling nutrient supply to benthic animals. Although the theoretical aspects of sinking mechanisms of particles (Hutchinson 1967; Lerman 1979) are complex and poorly understood, data on bulk particle flux provide insight into the lake ecosystem. Moreover, the sedimentation of seston is of practical interest as a parameter in models used for lake restoration, be it inserted as settling flux $\left(\mathrm{g} \mathrm{m}^{-2} \mathrm{~d}^{-1}\right)$, sinking velocity ( $\mathrm{m}$ $\mathrm{d}^{-1}$ ), or removal rate $\left(\mathrm{d}^{-1}\right)$ (Imboden and Lerman 1978).

Different methods have been used to determine the sedimentation of particulate material. The calculation of sedimentation rates by mass balance has many problems (Golterman 1975). Sediment coring and several dating methods (Krishnaswami and Lal 1978) are used to estimate sediment accumulation rates. A third approach consists of measuring sedimentation rates directly with sediment traps (Bloesch and Burns 1980). The advantage of the last is that it provides information on the sedimentation process itself.

If traps are used, sedimentation is usually measured at the deepest place in the lake. Although seasonal fluctuations and vertical variations in settling rate are recognized to be important, horizontal differences have rarely been taken into account (Chambers and Eadie 1981; Bloesch 1982). Moreover, we must be aware that traps measure gross sedimentation flux if sediment focusing and resuspension interfere, rather than providing the desired net sedimentation flux.

Our aim here is to investigate whether sedimentation rates measured at a midlake station actually represent a mean net sedimentation rate for the whole lake and may be used as such in modeling attempts for lake restoration (EAWAG Auftrag 4559). Differences betwcen nearshore and offshore sedimentation of Lake Hallwil, Switzerland, were compared with horizontal differences in particulate matter concentration, phytoplankton biomass, and primary production rates. The influence of river input and littoral sediment resuspension at nearshore stations was considered. In addition to horizontal differences, we present vertical and seasonal differences to further elucidate the process of sedimentation.

Lake Hallwil is a long $(8.4 \mathrm{~km})$ and rather narrow (max width, $1.6 \mathrm{~km}$ ) eutrophic lake in the Swiss lowland with a surface area of $10.2 \mathrm{~km}^{2}$, a mean depth of $28.6 \mathrm{~m}$, and a maximum depth of $48 \mathrm{~m}$ (Märki and Schmid 1983). Its shores are quite steep along the sides but shallow at both ends. There is one main river (inflow, $\sim 1.3 \mathrm{~m}^{3} \mathrm{~s}^{-1}$ ) at the south end, connecting Lake Baldegg with Lake Hallwil; eight small rivers along the side, with substantially diminished discharge 
during summer, contribute only about $25 \%$ of the total water input.

We thank J. Angehrn, S. Balmer, F. Boss, R. Carmesin, S. Eglin, and J. Gavrieli for assistance in fieldwork; E. Szabo, B. Ribi, and R. Illi for performing POC and PP analyses; A. Esenwein and H. Vonmont for performing $\mathrm{Ca}$ and $\mathrm{K}$ analyses; $\mathrm{U}$. Fischbacher and U. Steinemann for phytoplankton counting; H. R. Bürgi, R. Gächter, and the Water Protection Department of Canton Aargau for providing phytoplankton, POC, and chemical data for Lake Hallwil waters; and J.-M. Jaquet, J. Hilton, and W. D. Gardner for reviewing the manuscript.

\section{Methods}

Sedimentation rates were measured from May 1982 to May 1983 at seven stations and at different depths $(13,30$, and $43 \mathrm{~m})$ (Fig. 1). The lowest traps were $3 \mathrm{~m}$ above the bottom; i.e. the lake was $16 \mathrm{~m}$ deep at nearshore stations $1,3,5$, and $7,33 \mathrm{~m}$ at stations 2 and 6 , and $46 \mathrm{~m}$ at midlake station 4. Two parallel cylindrical traps $(70 \mathrm{~cm}$ high, $7 \mathrm{~cm}$ diam) in a frame (figure 8: Bloesch and Burns 1980) were exposed with a simple mooring system with anchor and subsurface buoys. Traps were exchanged biweekly, the supernatant water drained, and the two samples usually combined to one mixed sample for analysis. The two traps yielded fluxes within $\pm \leq 15 \%$ (Bloesch and Burns 1980).

Dry weight (DW) of sediments was determined gravimetrically by centrifuging about $500 \mathrm{ml}$ of the well shaken sample and drying at $50^{\circ} \mathrm{C}$ for at least 2 days. Particulate organic carbon (POC) was analyzed on preheated $\left(500^{\circ} \mathrm{C}\right)$ Whatman $\mathrm{GF} / \mathrm{F}$ glass-fiber filters $(0.7 \mu \mathrm{m})$ by ignition at $860^{\circ} \mathrm{C}$ and measuring $\mathrm{CO}_{2}$ in a Horiba-IR detector; inorganic carbon was removed during filtration by rinsing the filters with $0.1 \mathrm{~N} \mathrm{H}_{2} \mathrm{SO}_{4}$. Particulatc phosphorus (PP) was analyzed directly on $0.45-\mu \mathrm{m}$ Sartorius cellulose acetate filters (Bloesch and Gavrieli 1984) by a digestion procedure (Schmid and Ambühl 1965) and the molybdenum blue method of Vogler (1965). Ca:K ratios were determined directly in the dried sediments by X-ray fluorescence spectrometry (Philips PW 1450); in 25 selected samples, Ca was

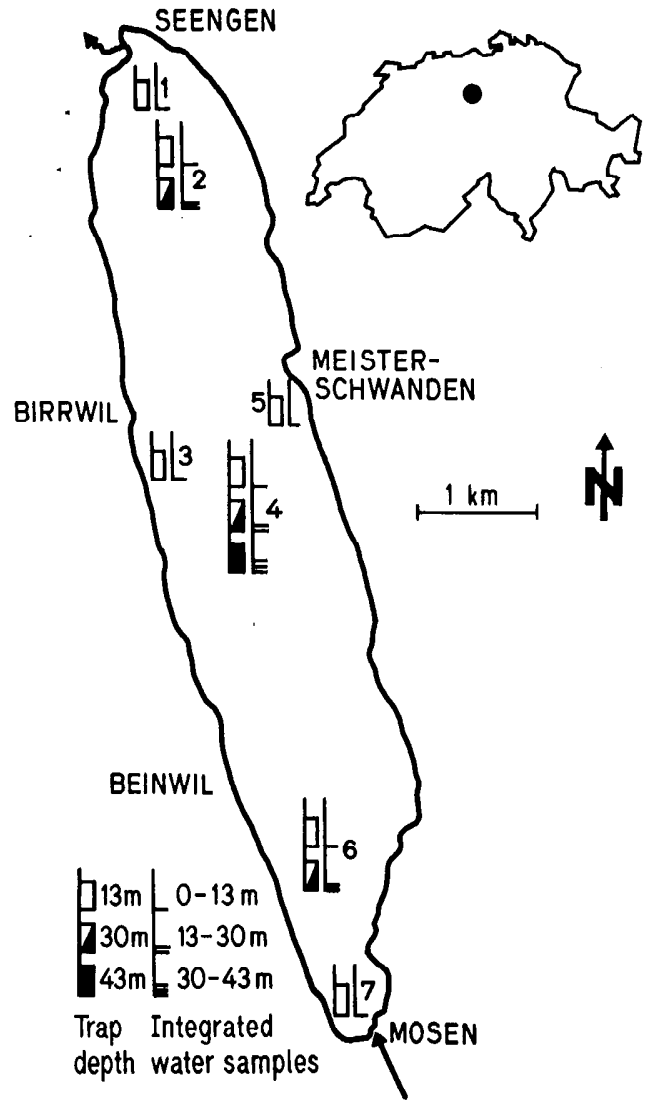

Fig. 1. Lake Hallwil: Sampling stations 1-7 and depth for sediment traps and water samples. Inset shows location of Lake Hallwil in Switzerland.

analyzed by plasma-spectrometry (ARL 34000 ) and $\mathrm{K}$ by atomic absorption spectrometry (Perkin-Elmer 400) after acid digestion (Schrader and Hein 1983).

In addition to the sediment trap program, on seven dates chosen at random we took water samples at all seven stations. POC and PP analyses of proportionally mixed samples for the water columns above the traps $(0-13 \mathrm{~m}, 13-30 \mathrm{~m}, 30-43 \mathrm{~m})$ were performed as above. Primary production was measured by the ${ }^{14} \mathrm{C}$ acid-bubbling method (Gächter and Mares 1979). Light intensity (PAR) was continuously recorded during the investigation. Daily production rates were calculated by relating the productivity per chlorophyll a (Am. Public Health Assoc. 1975, without correction for pheophytin) to light intensity (PAR) (Bührer et al. unpubl.). 


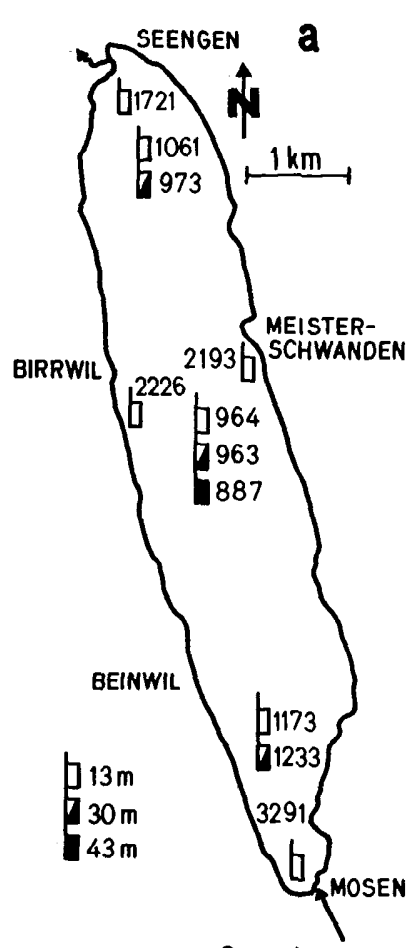

DW $\mathrm{g} \mathrm{m}^{-2} \mathrm{yr}^{-1}$
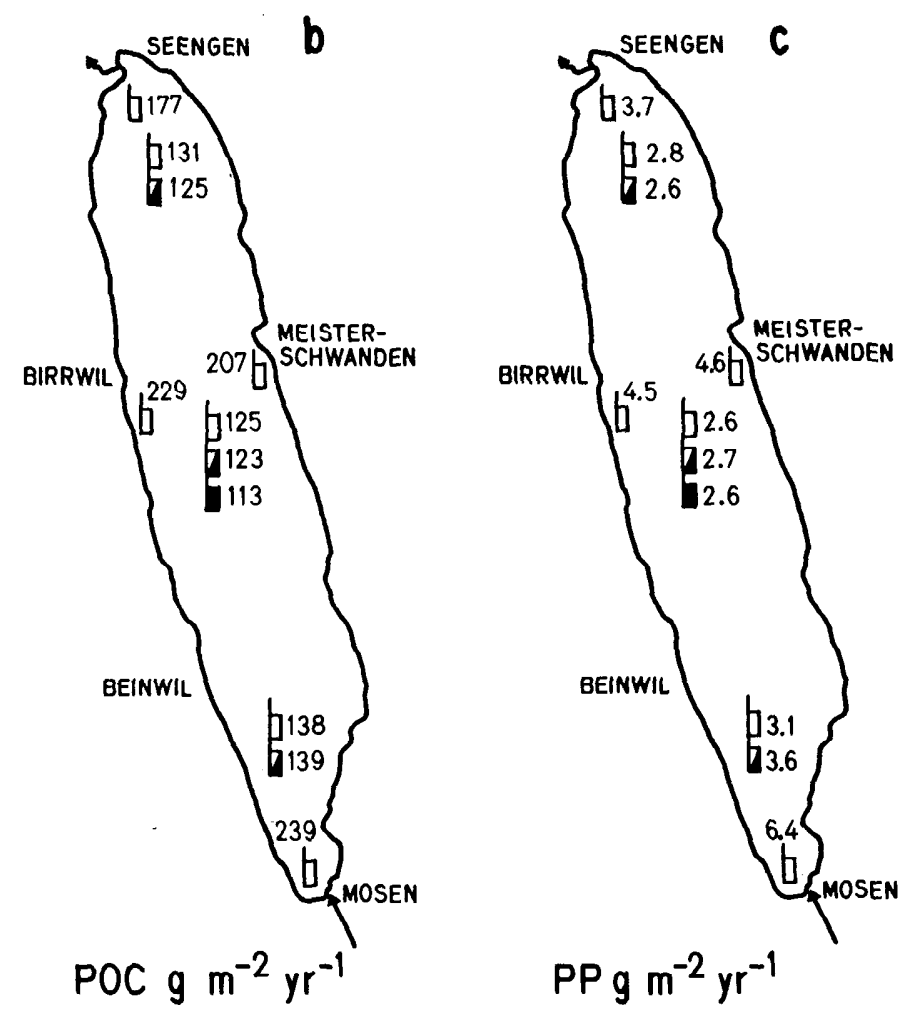

Fig. 2. Yearly DW, POC, and PP sedimentation rates in Lake Hallwil, 12-13 May 1982-11 May 1983.

Phytoplankton was counted in selected sediment and water samples by the Utermöhl technique and converted to biomass by cell volumes (Bürgi et al. 1985).

\section{Results}

The yearly sedimentation rates (Fig. 2) at the midlake station amounted to $887 \mathrm{~g}$ DW $\mathrm{m}^{-2} \mathrm{yr}^{-1}, 113 \mathrm{~g} \mathrm{POC}^{-2} \mathrm{yr}^{-1}$, and $2.6 \mathrm{~g}$ $\mathrm{PP} \mathrm{m} \mathrm{m}^{-2} \mathrm{yr}^{-1}$. Horizontal differences are evident, with all the nearshore stations showing increased sedimentation, although differences in vertical sedimentation were minor. The horizontal distribution of phytoplankton biomass sedimentation for selected periods showed the same pattern, but less distinctly (Fig. 3 ).

The seasonal fluctuations in sedimentation (Fig. 4) demonstrate that horizontal sedimentation differences can be observed throughout the year but especially in summer. They were in general identical for DW, POC, and PP. Bulk sedimentation from June through September 1982 induced by pri- mary production (Fig. 5) accounted for about 78,74 , and $69 \%$ of the total sedimentation rate for the year. Some small peaks followed during late fall. The sedimentation peak of summer 1983 began to develop just at the end of the sampling period. Biomass sedimentation was related to the maximum peak of standing crop in June-July 1982 (Fig. 6) but did not reflect the smaller biomass fluctuations in fall and winter. The phytoplankton peaks consisted mainly of diatoms and cryptomonads (March-April), greens (July), and blue-greens (September-October) in 1982. In March-April 1983 the phytoplankton community was dominated by a bloom of flagellates, contributing $90 \%$ to the total biomass; the contribution of only $43 \%$ to the sedimentation rates indicates a significant decomposition of these delicate algae in the epilimnion. The extremely low standing crops in May 1982 and 1983 could be attributed to zooplankton grazing (Bürgi et al. 1985).

The mean POC and PP content for all 

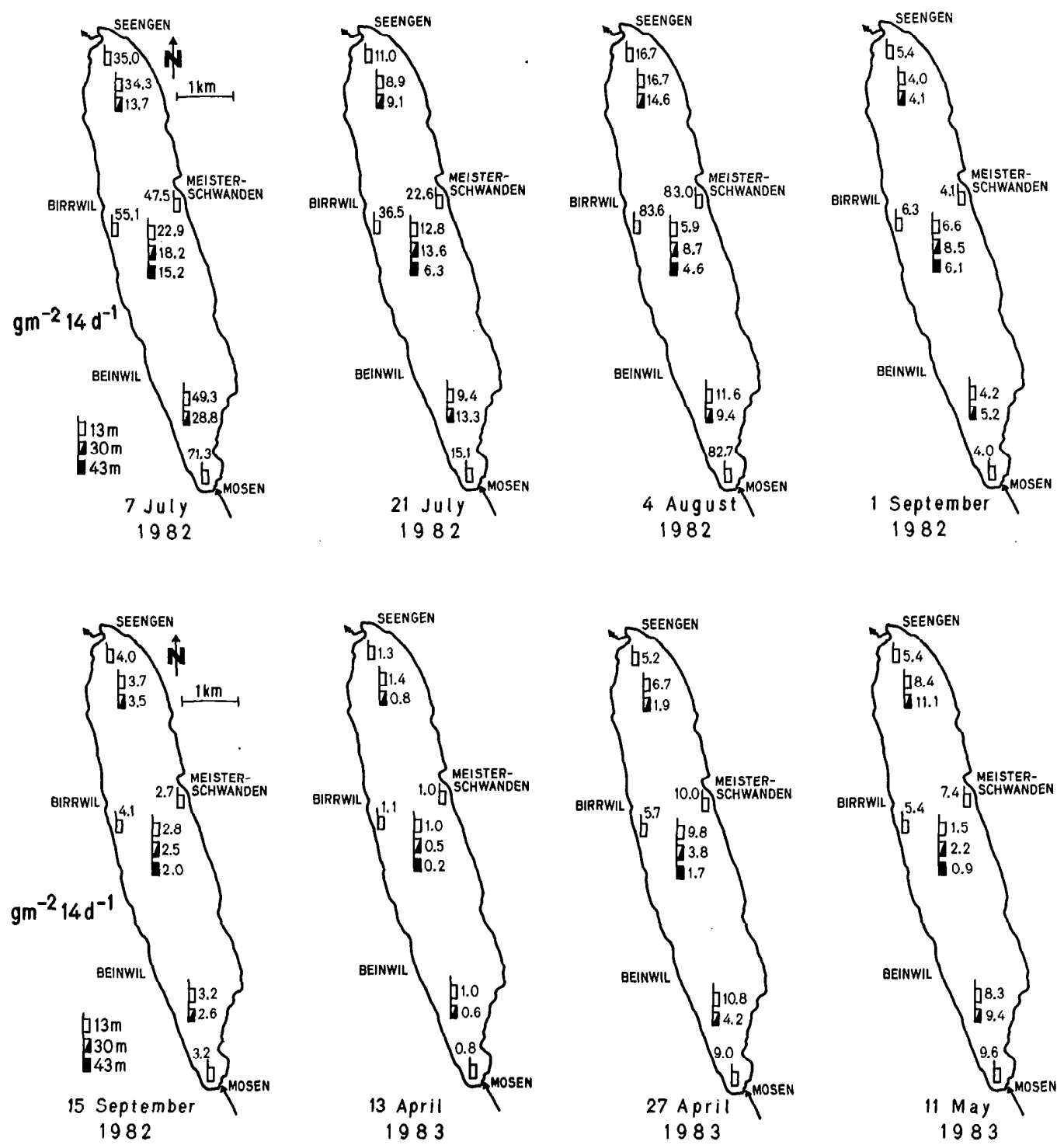

Fig. 3. Phytoplankton biomass sedimentation in Lake Hallwil during selected periods of summer 1982 and spring 1983.

stations and depths was $13.85 \%$ and $0.34 \%$ of the sedimented dry matter (DW). These values were markedly exceeded only in MayJune 1982 and May 1983 (sta. 2, 4, and 6, offshore) and in November-December 1982 in the upper trap at sta. 4 (Fig. 7). The seasonal differences (mean of POC and PP winter values $=1.17 \times$ mean of $P O C$ and $P P$ summer values) were smaller than the nearshore to offshore differences (mean of POC and PP offshore $=1.49 \times$ mean of POC and PP nearshore). The lower POC content in the material entrapped nearshore, especially at sta. 7, indicates some influence of allochthonous input or sediment resuspension.

The $\mathrm{C}: \mathrm{P}$ ratios in sedimented seston showed negligible vertical differences offshore and were higher in summer than in winter (Fig. 8a) as a result of phosphorus depletion (Gächter and Bloesch 1985). Hor- 

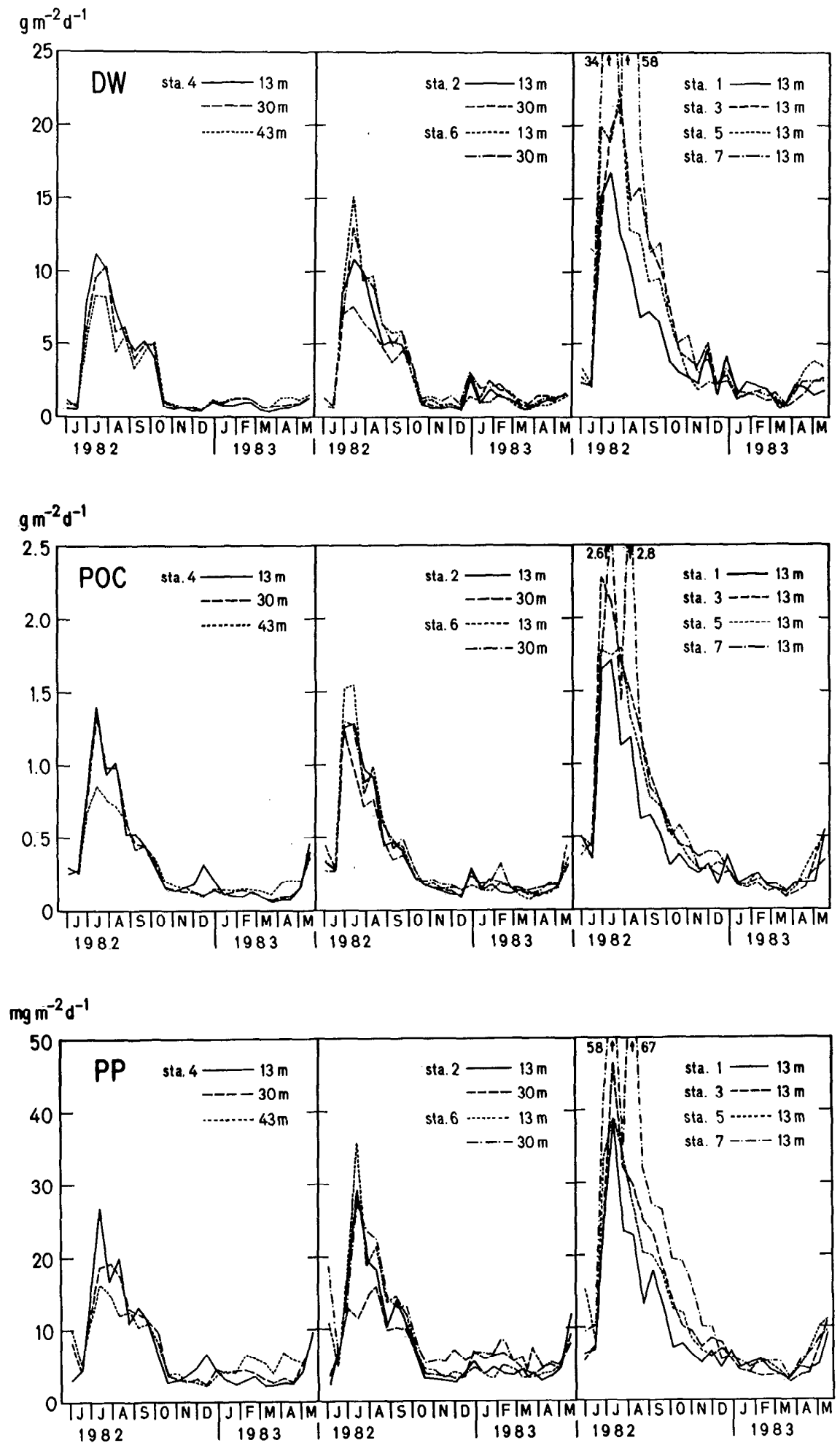

Fig. 4. Seasonal fluctuations in DW, POC, and PP sedimentation in Lake Hallwil, May 1982-May 1983. 


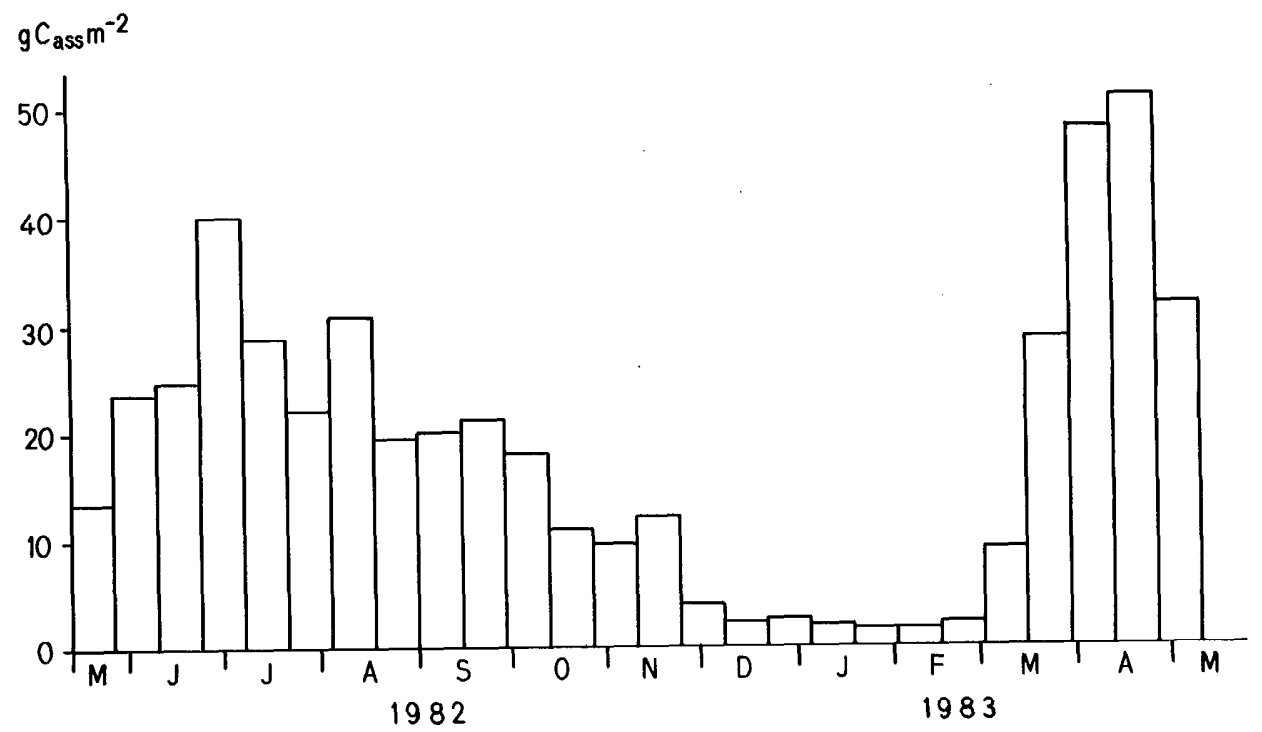

Fig. 5. Seasonal fluctuations in primary production $(0-10 \mathrm{~m})$ at the midlake station of Lake Hallwil, May 1982-May 1983.

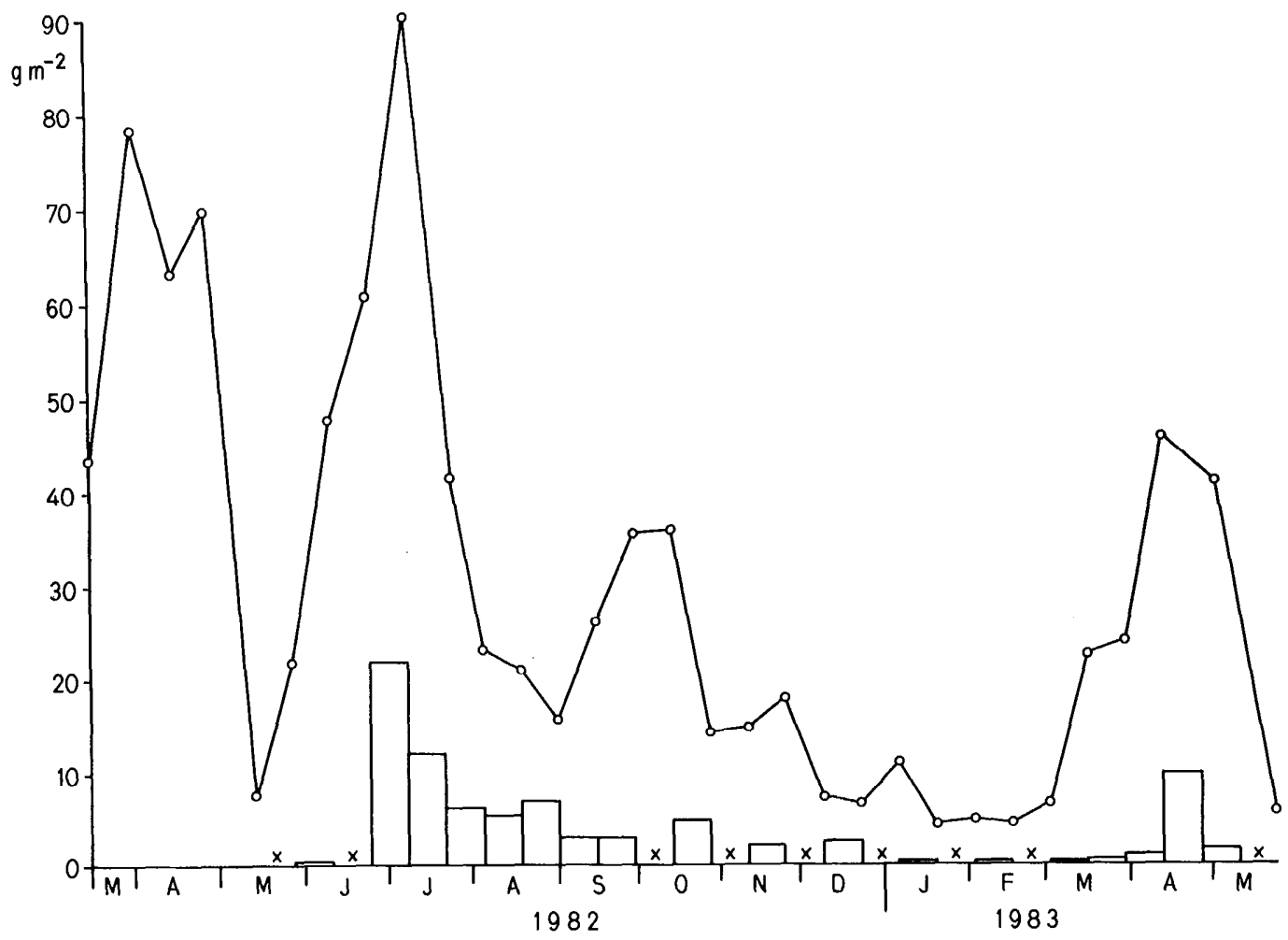

Fig. 6. Seasonal fluctuations in phytoplankton standing crop (0-13 m, line) and phytoplankton biomass sedimentation (at $13 \mathrm{~m}$, bars) at the midlake station of Lake Hallwil, May 1982-May 1983. (Not counted-×.) 

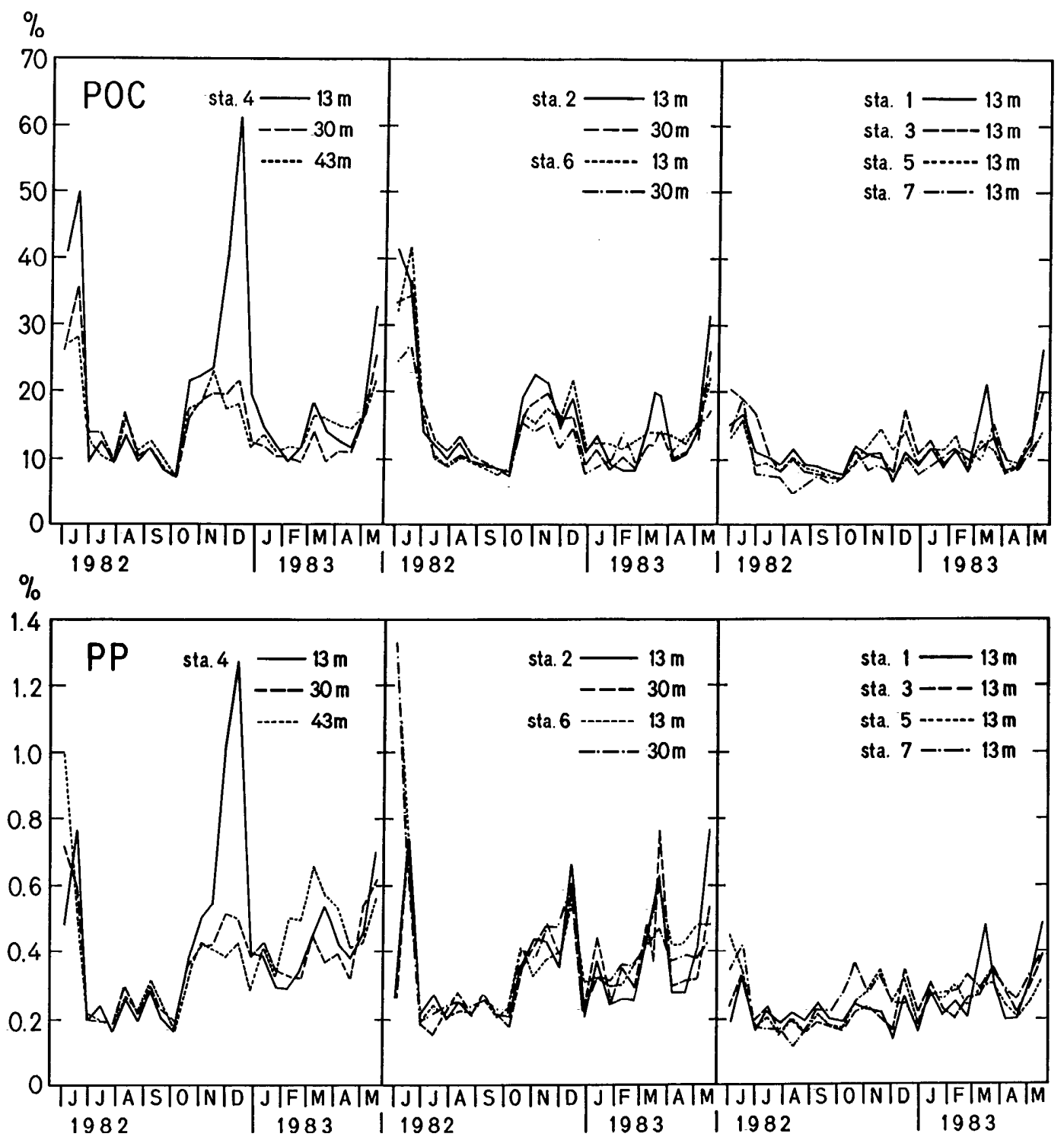

Fig. 7. POC and PP content (in \% of DW) of sedimented material in Lake Hallwil, May 1982-May 1983.

izontal differences were rather small; however, sta. 7 had the smallest values throughout the season, again indicating either allochthonous input of inorganic P-rich material by the main tributary or sediment resuspension.

The $\mathrm{Ca}: \mathrm{K}$ ratios were also lowest at sta. 7, apparently influencing sta. 6 (Fig. 8b). In summer, when autochthonous calcite pre- cipitation is dominating due to high primary productivity, $\mathrm{Ca}: \mathrm{K}$ ratios at offshore stations 2 and 4 were higher than at the nearshore stations; in winter, when productivity was low, horizontal differences were smaller and the relative sizes of ratios inshore and offshore were reversed. Some quantitative analyses performed at random showed that while the nearshore $\mathrm{Ca}$ and $\mathrm{K}$ 
fluxes were higher than the offshore fluxes, seasonal differences were considerably larger (Table 1).

To test the hypothesis that high nearshore concentrations in particulate matter and biomass could contribute to the increased nearshore sedimentation rates, we analyzed water samples at random. In contrast to the measured sedimentation fluxes (Fig. 2), POC and PP concentrations in the shallow north and south parts of the lake were only slightly increased, whereas nearshore stations 3 and 5 showed results similar to those at midlake sta. 4 (Fig. 9b, c). This was less pronounced for primary production (Fig. 9a), and the horizontal differences in phytoplankton biomass (Fig. 10) were negligible. (We attribute the few outliers to small-scale patchiness or counting variance rather than inshore-offshore variation.) The vertical differences in POC and PP concentrations and phytoplankton biomass offshore (Figs. $9,10)$, exceeding the horizontal differences considerably, generally decreased with increasing depth. The increase of POC and PP concentrations at depth in the midlake station (see also Fig. 12) is probably the result of resuspension of bottom sediment or sediment focusing.

\section{Discussion}

Our results clearly show horizontal differences in DW, POC, and PP sedimentation (Figs. 2-4, 7; Table 1); nearshore settling fluxes were 1.4-3.4 times those at the midlake station. Vertical sedimentation differences were minor, as the near-bottom traps at the offshore stations were not strongly influenced by bottom sediment resuspension. On the other hand, there were distinct vertical, but no significant horizontal, differences in primary production, phy-
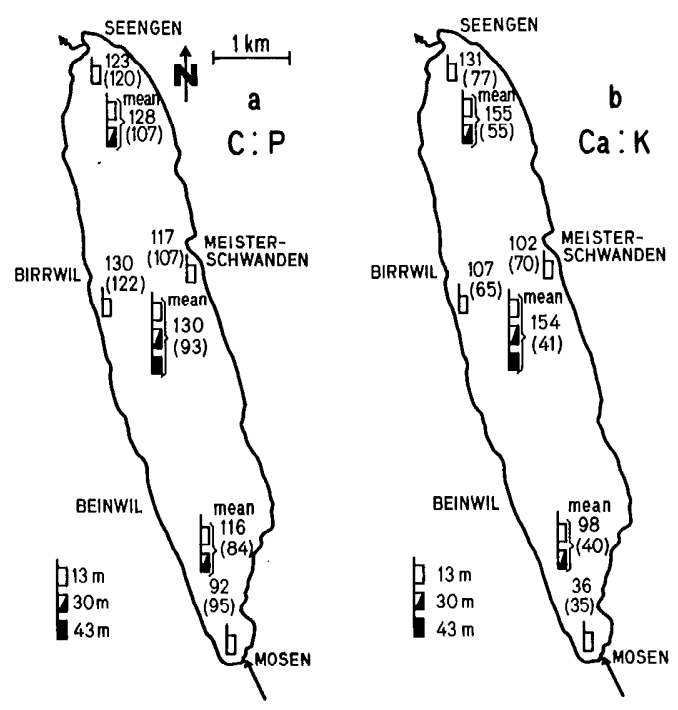

Fig. 8. Mean (depth and time averaged) $\mathrm{C}: \mathrm{P}$ and $\mathrm{Ca}: \mathrm{K}$ ratios in entrapped dry matter in Lake Hallwil during the periods of summer stratification May-October 1982 and winter turnover 1982-1983 (values in parentheses).

toplankton standing crop, and POC and PP concentrations (Figs. 9, 10), although there were slight increases at the north and south ends of the lake. Since in small lakes horizontal mixing by currents considerably exceeds vertical mixing by eddies (Imboden et al. 1983), horizontal differences in dissolved and suspended particulate substances are small and temporary. This was true of separate lake basins in Lake Zug (EAWAG Auftrag 4663), where midlake sedimentation rates did not show significant differences (Bloesch and Sturm 1986). The horizontal sedimentation differences in Lake Hallwil must therefore be attributed to the influence of the littoral zone, which accounts for $55 \%$ of the surface area in the shallow northern and southern parts of the

Table 1. Mean Ca and $\mathrm{K}$ settling fluxes ( $\left.\mathrm{mg} \mathrm{m}^{-2} \mathrm{~d}^{-1}\right)$ in Lake Hallwil, 1982-1983.

\begin{tabular}{|c|c|c|c|c|c|c|c|c|}
\hline & \multicolumn{2}{|r|}{ Nearshore } & \multicolumn{2}{|r|}{ Offshore } & \multicolumn{2}{|r|}{ Nearshore } & \multicolumn{2}{|r|}{ Offshore } \\
\hline & $n$ & $\mathrm{Ca}$ & $n$ & $\mathrm{Ca}$ & $n$ & $\mathbf{K}$ & $n$ & $\mathrm{~K}$ \\
\hline Jun $82^{*}$ & 2 & $380 \pm 59$ & - & - & 2 & $9.0 \pm 4.7$ & - & - \\
\hline Jul-Sep 82 & 4 & $3,006 \pm 1,395$ & 11 & $1,214 \pm 165$ & 4 & $68.3 \pm 83.1$ & 11 & $11.4 \pm 12.6$ \\
\hline Nov $82-$ Mar 83 & 4 & $265 \pm 130$ & 4 & $81 \pm 12$ & 4 & $6.3 \pm 5.6$ & 4 & $2.3 \pm 0.6$ \\
\hline
\end{tabular}



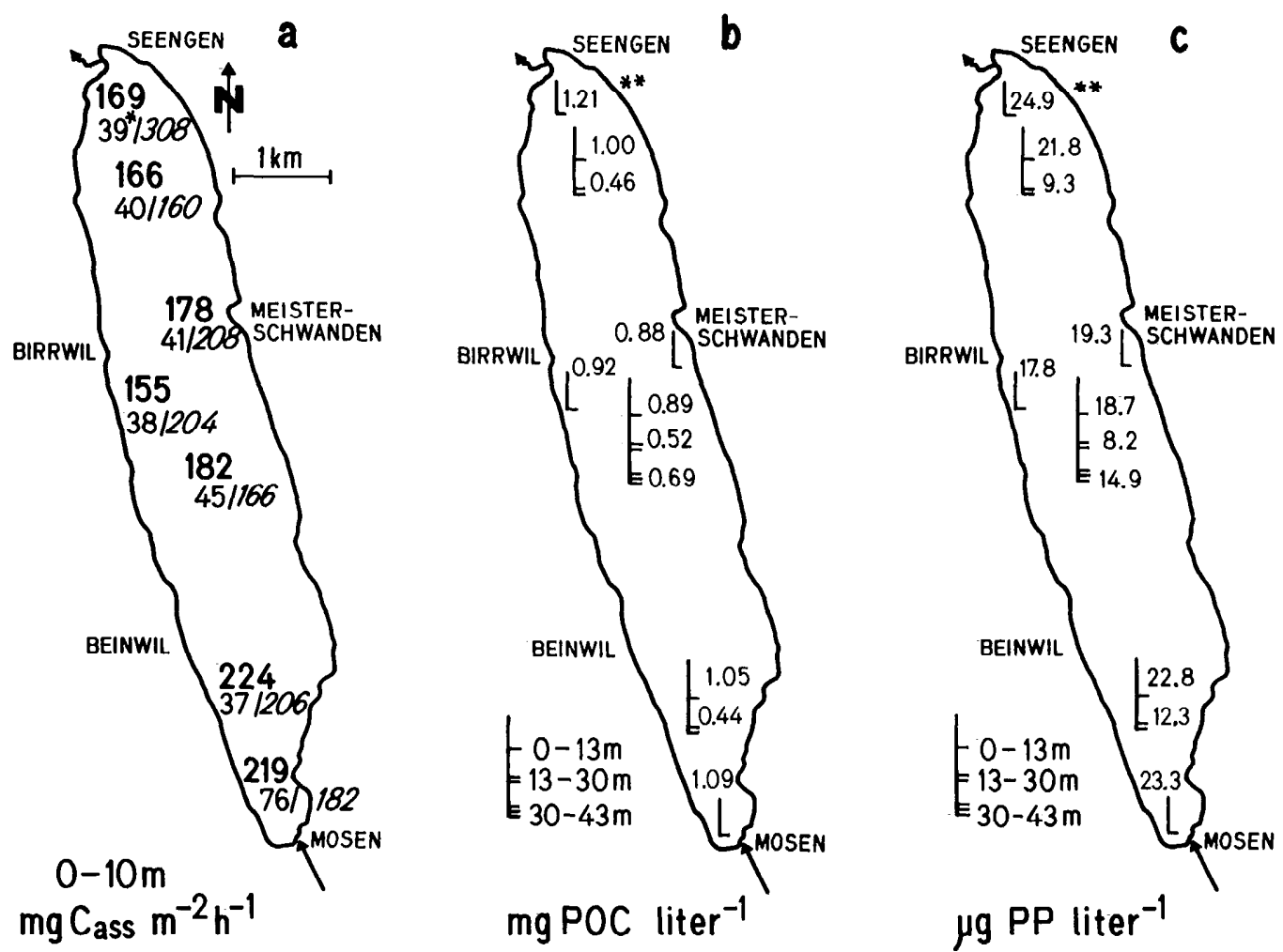

Fig. 9. Horizontal and vertical distribution of primary production and POC and PP concentrations in Lake Hallwil during selected periods of summer 1982 and spring 1983. Primary production: Heavy numbers - mean of four values during stratification from $15 \mathrm{July,} 2$ August, 8 September, and 20 October 1982; light numbersmean of two values during turnover from 9 March and 9 May 1983; italic numbers-extremely high spring production on 11 April 1983 caused by a flagellate bloom. Interpolated value of 9 March shown with an asterisk. POC and PP concentration: Mean of all seven values from the same dates. Because of partial ice-cover at the north end of the lake, station 1 was not sampled on 9 March and is shown with a double asterisk.

lake and $20 \%$ of the overall lake area. (We consider the littoral zone, depth limited by the tropholytic layer by definition, to extend down to $13 \mathrm{~m}$, the lower border of the epilimnion, for reasons of turbulence and wave dynamics: depth $\leq$ wavelength/2; Smith 1979.)

Sedimentation in the littoral zone can be affected by many factors, such as increased productivity, autochthonous input by macrophytes and water fowl, allochthonous input, and bottom resuspension, the last being dependent on the morphometry of the shoreline and the main directions of wind action. As shown in Figs. 9 and 10, neither primary production nor phytoplankton standing crop was significantly increased at nearshore stations. For many years macrophyte density has been reduced significantly due to eutrophication, and nearshore traps could be seen visually not to be contaminated by plant debris or bird excrement.

Most of the 10 mechanisms accounting for sediment distribution in small lakes (Hilton et al. 1986) can be excluded as effective processes in Lake Hallwil: Riverine

Fig. 10. Horizontal distribution of phytoplankton standing crop in Lake Hallwil during selected periods of summer 1982 and spring 1983. 

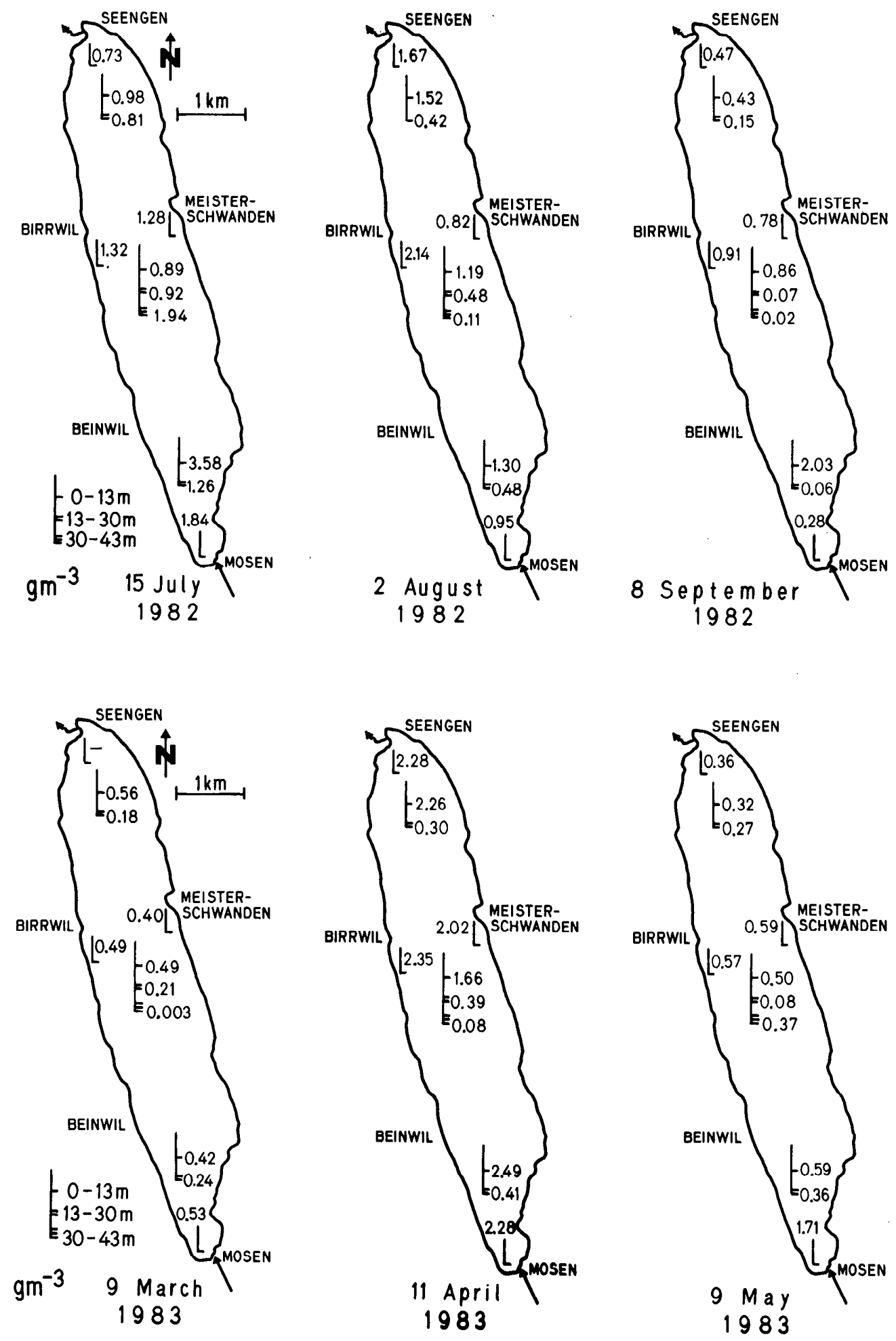
influence (delta and plume formation) is of limited local character only. We estimated the impact of allochthonous input, as no river load data are available, by correlating the substitute precipitation (measured by SMA 1983a) with sedimentation rates. Spearman tests showed good overall lake correlation ( $>95 \%$ significance) for DW, $\mathrm{POC}, \mathrm{PP}, \mathrm{Ca}$, and $\mathrm{K}$ sedimentation, indicating some allochthonous influence. However, as nearshore stations were not affected more than offshore stations, we assumed allochthonous particle input to be of minor importance. The tributary rivers are small, except that nearshore station 7 receives the discharge of the Aa River, outlet of nearby Lake Baldegg, and of a water treatment plant. This station is situated in a bay naturally separated from the main pelagic zone by a rim on the east shore and cannot be considered representative for overall lake sedimentation. In view of the rather small wind stress, the depth and morphometry of the lake prevent significant effects of intermittent complete mixing of particulate material. (Continuous complete mixing implies even sediment deposition over the lakebed, a situation not found in Lake Hallwil.) Current erosion/redeposition is unlikely to take place in small lakes with an even bed shapc. Organic degradation differences in aerobic (littoral) and anaerobic (profundal) zones may be present but cannot cause significant differences in horizontal sediment distribution because traps were left for only 14 days and the decay rate of organic $C$ is supposed to be $<1 \%$ per day (Gardner et al. 1983; Knauer et al. 1984). Slumping and sliding may occur occasionally at the broad sides of the lake with a slope of $20-30 \%$ and could account for sediment focusing; however, no such event was recorded by the traps, which did not show an unusually high sedimentation peak during our investigation. Of the two remaining mechanisms, peripheral wave action seems to outcompete random distribution of sediment, according to the model of Hilton (1985).

Peripheral wave action reflects resuspension of bottom sediments and implies horizontal sediment transportation and thus sediment focusing (Hilton 1985). However, focusing offshore was not prominent during summer stratification: vertical differences in trap catches (Fig. 2) and in the $C: P$ ratios of trapped material (Gächter and Bloesch 1985 ) were not significant. Only during winter turnover (January-February 1983) did hypo traps show a slight increase when compared to the epi traps, indicating some focusing during this period of greater turbulence.

The same approach can be made by the assumption that, especially during summer stratification, the influence of resuspension diminishes toward the center of the lake because of increasing depth and distance from shore so that nearshore sedimentation would significantly exceed sedimentation offshore. This was found in Lake Hallwil, as DW, POC, and PP sedimentation showed an exponential relationship to the distance from the lake shore by fitting the regression equation $y=a+b \times \log x\left(r^{2}=0.88-0.93\right)$, where $y$ is the measured sedimentation flux per exposure time and $x$ is the shortest distance from the sampling station to lakeshore (Banks and Nighswander 1982). The special situation of nearshore station 7 again is shown by the drastic decrease of the regression coefficient $r^{2}$ from $0.88-0.93$ to $0.40-$ 0.62 if this station is included in the data sets. This relationship was less distinct in winter $\left(r^{2}=0.05-0.79\right)$, indicating some sediment transport from nearshore locations toward the center of the lake. However, regression calculations including the whole data set yielding $r^{2}=0.88-0.93$ show that processes during summer may outcompete those during winter.

We considered several approaches to quantify bottom sediment resuspension, sediment focusing, or both in the profundal of the lake. The method of Lastein (1976) who took entrapped Chironomus larvae as a measure of bottom sediment resuspension could not be used, since no significant numbers of benthic animals were found in our traps. Simola (1981) used the percentage of littoral diatoms in trap material to determine resuspension; this method is very laborious and our limited data were not sufficient for its application. The suggestion of Fuhs (1973) to quantify resuspension by 
Table 2. Resuspension (in \% of bottom trap catch) at the offshore stations in Lake Hallwil 1982-1983. Mean values $\pm \mathrm{SD}$; $n$-number of trap exposure periods (14 days); value in parentheses-number of trap exposure periods with no resuspension (epi trap catch $\geq$ hypo trap catch).

\begin{tabular}{cccc}
\hline \hline & $\begin{array}{c}27 \text { May-15 Sep } 82 \\
n=8\end{array}$ & $\begin{array}{c}12 \text { May-27 May } 82 \\
\text { Sep } 82-11 \text { May } 83 \\
n=18\end{array}$ & $\begin{array}{c}\text { Total year 1982-1983 } \\
n=26\end{array}$ \\
\hline DW & & & $14.5 \pm 12.8(7)$ \\
Sta. 2 & $0.8 \pm 2.3(7)$ & $20.5 \pm 10.6(0)$ & $20.1 \pm 17.4(6)$ \\
Sta. 4 & $5.3 \pm 14.6(6)$ & $26.6 \pm 14.4(0)$ & $21.2 \pm 16.3(6)$ \\
Sta. 6 & $5.3 \pm 12.7(6)$ & $28.3 \pm 12.2(0)$ & $10.0 \pm 11.8(9)$ \\
POC & & & $14.5 \pm 18.3(11)$ \\
Sta. 2 & $1.1 \pm 2.5(6)$ & $13.9 \pm 12.2(3)$ & $12.5 \pm 12.8(7)$ \\
Sta. 4 & $2.0 \pm 5.5(7)$ & $20.1 \pm 19.3(4)$ & $15.6 \pm 15.4(10)$ \\
Sta. 6 & $3.2 \pm 4.5(4)$ & $16.6 \pm 13.2(3)$ & $21.3 \pm 23.0(11)$ \\
PP & & & $21.0 \pm 16.1(4)$ \\
Sta. 2 & $0.7 \pm 2.0(7)$ & $22.2 \pm 14.1(3)$ & \\
Sta. 4 & $3.6 \pm 6.6(6)$ & $29.2 \pm 23.4(5)$ & \\
Sta. 6 & $7.4 \pm 8.6(3)$ & $27.1 \pm 15.1(1)$ & \\
\hline
\end{tabular}

comparing results from trap collections during calm weather and under stormy conditions has the disadvantage that the periods of trap exposure are not the same. No resuspension was found during the year by using the formula of Gasith (1975), which relates the organic content of bottom sediments (cores) with that of entrapped material, probably because the organic fraction of tripton was not accurately measured.

The method of Gardner (1977) and Bloesch (1982) of comparing epi and hypo trap catches yielded resuspension from 0 to $1.6 \mathrm{~g} \mathrm{~m}^{-2} \mathrm{~d}^{-1}$ for DW, 0 to $132 \mathrm{mg} \mathrm{m}^{-2}$ $\mathrm{d}^{-1}$ for POC, and 0 to $7.9 \mathrm{mg} \mathrm{m}^{-2} \mathrm{~d}^{-1}$ for PP. These are maximum values, since possible mineralization in the epi traps is not considered. Although resuspension varied considerably between the 2-week trap exposures, two distinct periods could be distinguished (Table 2). From 27 May to 15 September almost no resuspension occurred offshore, whereas a resuspension of 13.9-29.2\% (mean $22.7 \pm 5.4$ for all stations and parameters) was calculated for the periods of September to May. These periods do not exactly coincide with summer stratification and winter turnover, as mixing occurs in November rather than in September. Resuspension/focusing events are positively correlated with wind stress (Fig. 11); strong winds during winter are effective because the lake was frozen only partially for a short period in March 1983. However, little resuspension of profundal sediments is indicated, as the yearly POC sedimentation at the midlake station (Fig. 2) was only $24 \%$ of the yearly primary production of $481 \mathrm{~g}$ $\mathrm{m}^{-2} \mathrm{yr}^{-1}$ (Hilton 1985). From these findings we conclude that in Lake Hallwil resuspension and redeposition take place in the littoral zone throughout the year and that horizontal sediment transportation (sediment focusing) occurs only in winter, when wind and turbulence are increased.

One enigma, however, remains. An almost unchanged suspension of $P O C$ and PP above the lake bottom, extending usually 5-8 $\mathrm{m}$ and possibly affecting the hypo traps, could be observed at the midlake station during the entire investigation (Fig. 12). The mean increase in concentration from 30-35 m to $40-45 \mathrm{~m}$ was $7.9 \mathrm{mg} \mathrm{m}^{-3}$ for PP and $120.8 \mathrm{mg} \mathrm{m}^{-3}$ for POC, which corresponds to about 90 and $50 \%$ of the $30-35-\mathrm{m}$ means. It is not clear whether this "boundary layer" can be compared with the nepheloid layers found in the ocean and in the Great Lakes (Gibbs 1974; Biscaye and Eittreim 1977; Chambers and Eadie 1981; Eadie et al. 1984) and whether it originates from in situ resuspension or from peripheral wave action and subsequent horizontal transport by nearbottom currents. Near-bottom currents in the profundal of $1-2 \mathrm{~cm} \mathrm{~s}^{-1}$ are possible; such values have been recorded in nearby 


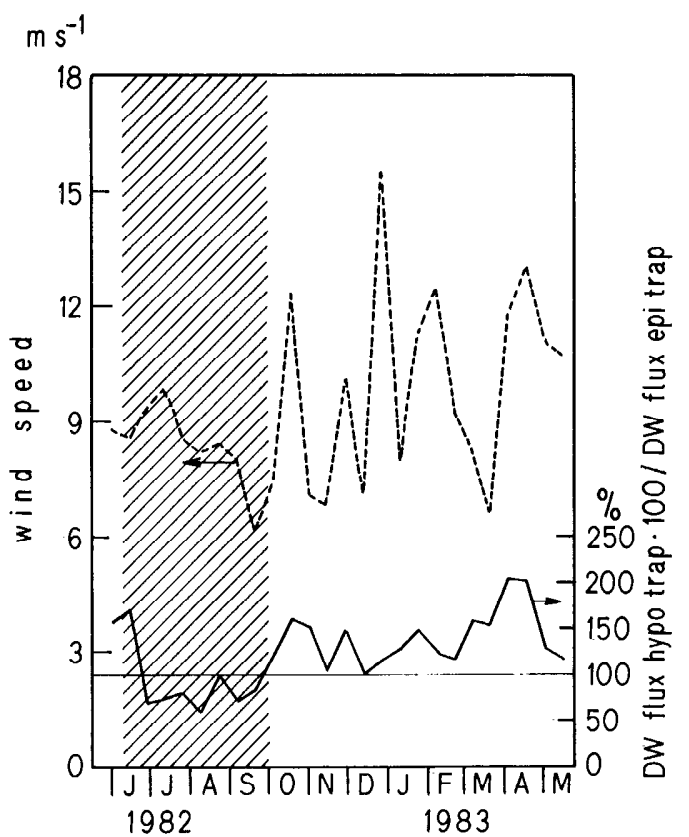

Fig. 11. Comparison of maximum wind speed in Zürich (fortnight mean of daily maxima, data from SMA $1983 b$ ) with the relative vertical difference of DW sedimentation in Lake. Hallwil (midlake station 4). Shaded area is period of no resuspension.

Lake Baldegg which has similar morphometry (Lemmin et al. 1985; Imboden and Lemmin unpubl. data). Terwindt (1977) and Rosa et al. (1983) reported that bottom currents of a few $\mathrm{mm}$ to $\mathrm{cm} \mathrm{s}^{-1}$ can cause resuspension of flocculent sediments; however, our hypo traps did not overtrap to a great extent when compared to the epi traps. Thus, we assume that particles suspended near the bottom are small (slightly above the $0.45-0.7-\mu \mathrm{m}$ range of the filters used) and have such a low sinking velocity that they do not significantly contaminate the hypo traps. In nearby Lake Sempach POC fractionation showed an increase of the fraction $<3 \mu \mathrm{m}$ with depth from 10 to $30 \%$, but a decrease in the traps from 10 to $7 \%$ (Uehlinger and Bloesch in prep.; see also $\mathrm{Mu}-$ droch 1984), supporting this hypothesis. In addition, the sinking velocity of small particles in the deep hypolimnion may be reduced by the density gradient caused by nutrient release from anaerobic bottom sediments.
Table 3. Yearly DW, POC, and PP sedimentation

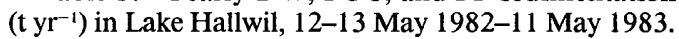

\begin{tabular}{|c|c|c|c|}
\hline Calculation based on & DW & POC & PP \\
\hline \multicolumn{4}{|l|}{ Midlake area $\left(5.1 \mathrm{~km}^{2}\right)$} \\
\hline Single Sta. 4 & 9,052 & 1,154 & 26.8 \\
\hline $\begin{array}{l}\text { Corrected for resus- } \\
\text { pension }\end{array}$ & 8,378 & 1,057 & 24.1 \\
\hline \multicolumn{4}{|l|}{ Offshore area $\left(6.15 \mathrm{~km}^{2}\right)$} \\
\hline $\begin{array}{l}\text { Areal mean of Sta. 2, } \\
\quad 4,6\end{array}$ & 9,813 & 1,225 & 28.2 \\
\hline $\begin{array}{l}\text { Corrected for resus- } \\
\text { pension }\end{array}$ & 9,076 & 1,125 & 25.4 \\
\hline $\begin{array}{l}\text { Arithmetic mean of } \\
\text { Sta. } 2,4,6\end{array}$ & 10,521 & 1,284 & 29.9 \\
\hline $\begin{array}{l}\text { Corrected for resus- } \\
\text { pension }\end{array}$ & 9,737 & 1,182 & 26.9 \\
\hline \multicolumn{4}{|c|}{ Total lake area $\left(10.2 \mathrm{~km}^{2}\right)$} \\
\hline $\begin{array}{l}\text { Areal mean of Sta. } \\
1-7 \\
\text { Arithmetic mean of }\end{array}$ & 13,209 & 1,465 & 33.0 \\
\hline Sta. $1-7$ & 18,250 & 1,792 & 40.7 \\
\hline
\end{tabular}

Having checked mcasured sedimentation rates in the lake for resuspension, we can calculate net sedimentation to use for a mass balance or a lake model. The hypo trap results at the offshore stations may be corrected by $20 \%$ during winter, but remain uncorrected for the summer period. As the latter provides bulk sedimentation, the yearly sedimentation rates in Fig. 2 need be corrected by only $7-10 \%$, which is within the range of error of the trap method (Bloesch and Burns 1980). The sedimentation rate measurements for the nearshore stations are not representative for the whole lake, as they are influenced by peripheral wave action (station 7 by allochthonous input as well).

Resuspension must be taken into account when calculating the yearly net total loss $(t$ $\mathrm{yr}^{-1}$ ) of DW, POC, and PP to the lake sediments (Table 3). Calculations based on all seven stations yield losses to the sediments 23-102\% greater than the true net sedimentation needed for a lake mass balance and must be discarded. When the offshore stations are uscd in the calculations, areaweighted sedimentation rates should be used instead of simple arithmetic means. Net DW, POC, and PP sedimentation rates based on these stations exceeded those based on midlake station 4 only by $5-8 \%$. On the 


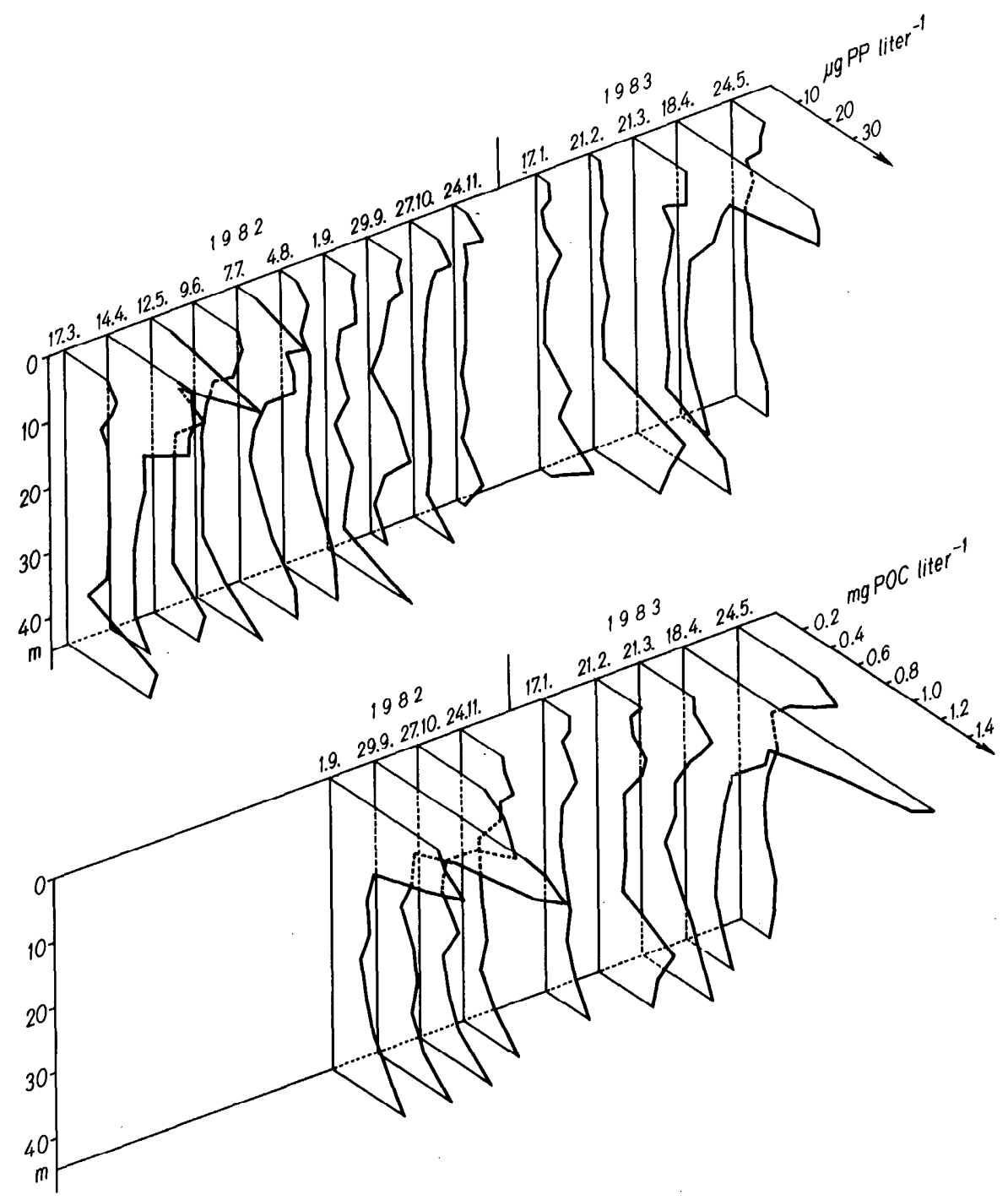

Fig. 12. Vertical profiles of PP and POC distribution at the midlake station in Lake Hallwil, March 1982May 1983.

other hand, the calculated sedimentation loss is decreased by $7-10 \%$ when winter resuspension of $20 \%$ is included. Since these differences are within the methodological error range of $\pm 10 \%$, we conclude that in Lake Hallwil the sedimentation rates measured at the midlake station are representative for the lake and can be used for mass balance and modeling. The problems of transforming net settling flux to settling velocity by the equation

velocity $=$ flux/concentration, as used for the dynamic model of Lake Hallwil (EAWAG Auftrag 4559) will be discussed elsewhere (Bloesch and Sturm 1986).

\section{Conclusions}

Sediment traps are useful for studying the process of particle settling and measuring sedimentation rates. Trap investigations of horizontal sedimentation differences in lakes have rarely been performed. However, they are needed, because these differences cannot be predicted at present. The contradiction 
of results is demonstrated by a review of the sparse literature. Davis (1973) found increased pollen sedimentation rates in the center of the shallow Frains Lake due to littoral deposition, resuspension, horizontal transport, and redeposition in the profundal regions (sediment focusing: Likens and $\mathrm{Da}$ vis 1975). The same mechanism was postulated for fossil zooplankton remains by Mueller (1964). Horizontal transport was also found for DW, POC, and PP in Lake Erie (Bloesch 1982), but nearshore settling fluxes exceeded offshore fluxes, as larger particles were repeatedly deposited at the site of resuspension. Similar results were reported by Serruya (1977) for Lake Kinneret. On the other hand, Lawacz (1969) found almost no horizontal sedimentation differences in Lake Mikolajki, except for one station in the immediate vicinity of a port with a twofold sedimentation increase; however, the traps were only exposed once in October. No horizontal sedimentation differences were reported by Moeller and Likens (1978) for Mirror Lake.

It is necessary to know the mechanisms of bottom sediment transport when measuring sedimentation rates with traps. The model of Hilton (1985) now provides a promising scheme to check a lake for the importance of these processes. In the cases where trap catches overestimate sedimentation rates, the main reasons are sediment resuspension, focusing, sliding, or slumping. In addition to a single hypo trap, concomitant measurements by a vertical series of traps or analysis of cores are recommended.

There is evidence that sediment traps at a midlake station of a deep lake can be used to properly measure the net settling flux of particulate material, as shown for Lake Hallwil. Bottom sediment resuspension in the profundal zone of this lake, although present during turnover, can be neglected. This is also demonstrated by cores taken at the midlake station which show nicely laminated structure (H. Ambühl pers. comm.). As the deep hypolimnion stays anaerobic throughout the year and therefore benthic organisms are not abundant (F. Stössel pers. comm.), this is of minor ecological significance. However, resuspension in the littoral zones may have a significant effect on the overall lake nutrient cycling.

\section{References}

American Public Health Association. 1975. Standard methods for the examination of water and wastewater.

Banks, H. H., AND J. F. Nighswander. 1982. The application of a new method for the determination of particulate deposition onto a lake. Ecology 63: 1254-1288.

Biscaye, P. E., AND S. L. EitTreim. 1977. Suspended particulate loads and transports in the nepheloid layer of the abyssal Atlantic Ocean. Mar. Geol. 23: 155-177.

BLOESCH, J. 1982. Inshore-offshore sedimentation differences resulting from resuspension in the eastern basin of Lake Erie. Can. J. Fish. Aquat. Sci. 39: 748-759.

— AND N. M. Burns. 1980. A critical review of sedimentation trap technique. Schweiz. Z. Hydrol. 42: 15-55.

- , AND J. GAVRIELI. 1984. The influence of filtration on particulate phosphorus analysis. Int. Ver. Theor. Angew. Limnol. Verh. 22: 155-162.

- AND M. STURM. 1986. Settling flux and sinking velocities of particulate phosphorus (PP) and particulate organic carbon (POC) in Lake Zug, Switzerland, p. 479-488. In P. G. Sly [ed.], Sediments and water interactions. Springer.

Bürgi, H. R., P. WEBer, AND H. BACHMANN. 1985. Seasonal variations in the trophic structure of phyto- and zooplankton communities in lakes in different trophic states. Schweiz. Z. Hydrol. 47: 197224.

Chambers, R. L., AND B. J. Eadie. 1981. Nepheloid and suspended particle matter in southeastern Lake Michigan. Sedimentology 28: 438-447.

Davis, M. B. 1973. Redeposition of pollen grains in lake seđiments. Limnol. Oceanogr. 18: 44-52.

EAdie, B. J., R. L. Chambers, W. S. GaRdNER, AND G. L. BELL. 1984. Sediment trap studies in Lake Michigan: Resuspension and chemical fluxes in the southern basin. J. Great Lakes Res, 10: 307321.

FUHS, G. W. 1973. Improved device for the collection of sedimenting matter. Limnol. Oceanogr. 18: 989_ 993.

GÄCHTER, R., AND J. BLOESCH. 1985. The variation in the $C: P$ ratio of suspended and entrapped particulate material in lakes. Hydrobiologia 128: 193200.

$\longrightarrow$, AND A. MARES. 1979. Comments on the acidification and bubbling method determining phytoplankton production. Oikos 33: 69-73.

GARDNER, W. D. 1977. Fluxes, dynamics and chemistry of particulates in the ocean. Ph.D. thesis, Mass. Inst. Technol./Woods Hole Oceanogr. Inst. - , K. R. Hinga, AND J. MarRA. 1983. Observations on the degradation of biogenic material in the deep ocean with implications on accuracy of sediment trap fluxes. J. Mar. Res. 41: 195-214. 
GASITH, A. 1975. Tripton sedimentation in eutrophic lakes-simple correction for the resuspended matter. Int. Ver. Theor. Angew. Limnol. Verh. 19: 116-122.

GIBBS, R. J. [ED.]. 1974. Suspended solids in water. Plenum.

Golterman, H. L. 1975. Physiological limnology. An approach to the physiology of lake ecosystems, p. 357-402. In Developments in water science, $v$. 2. Elsevier.

HiLton, J. 1985. A conceptual framework for predicting the occurrence of sediment focusing and sediment redistribution in small lakes. Limnol. Oceanogr. 30: 1131-1 143.

- J. P. Lishman, And P. V. Allen. 1986. The dominant processes of sediment distribution and focusing in a small, eutrophic, monomictic lake. Limnol. Oceanogr. 31: 125-133.

Hutchinson, G. E. 1967. A treatise on limnology, v. 2. Wiley.

IMBoden, D. M., U. Lemmin, T. Joller, AND M. SCHURTER. 1983. Mixing processes in lakes: Mechanisms and ecological relevance. Schweiz. Z. Hydrol. 45: 11-44.

$\longrightarrow$, AND A. LeRman. 1978. Chemical models of lakes, p. 341-356. In A. Lerman [ed.], Lakes: Chemistry, geology, physics. Springer.

Knauer, G. A., D. M. Karl, J. H. Martin, and C. N. HuNTER. 1984. In situ effects of selected preservatives on total carbon, nitrogen and metals collected in sediment traps. J. Mar. Res. 42: 445462.

KRISHNASWAMI, S., AND D. LAL. 1978. Radionuclide limnochronology, p. 153-177. In A. Lerman [ed.], Lakes: Chemistry, geology, physics. Springer.

LASTEIN, E. 1976. Recent sedimentation and resuspension of organic matter in eutrophic Lake Esrom, Denmark. Oikos 27: 44-49.

LAWACZ, W. 1969. The characteristics of sinking materials and the formation of bottom deposits in a eutrophic lake. Mitt. Int. Ver. Theor. Angew. Limnol. 17, p. 319-331.

LEMmin, U., M. SChurter, D. M. IMBODEN, T. JOLLER, AND H. ABegGlen. 1985. An instrument for measuring small bottom currents in lakes. Limnol. Oceanogr. 30: 1116-1122.

Lerman, A. 1979. Gcochemical processes. WileyInterscience.

Likens, G. E., AND M. B. DAvis. 1975. Post-glacial history of Mirror Lake and its watershed in New Hampshire, U.S.A.: An initial report. Int. Ver. Theor. Angew. Limnol. Verh. 19: 982-993.
MÄRKI, E., AND M. SChMID. 1983. Der Zustand des Hallwilersees. Wasser, Energie, Luft 75: 105-112.

Moeller, R. E., AND G. E. Likens. 1978. Seston scdimentation in Mirror Lake, New Hampshire, and its relationship to long-term sediment accumulation. Int. Ver. Theor. Angew. Limnol. Verh. 20: $525-530$.

MudRoCH, A. 1984. Chemistry, mineralogy, and morphology of Lake Erie suspended matter. J. Great Lakes Res. 10: 286-298.

MuelleR, W.P. 1964. The distribution of cladoceran remains in surficial sediments from three northern Indian lakes. Invest. Ind. Lakes Streams 6: 1-64.

Rosa, F., J. O. NRIAGU, H. K. Wong, AND N. M. BuRNS. 1983. Particulate flux at the bottom of Lake Ontario. Chemosphere 12: 1345-1354.

Schmid, M., AND H. AmbüHL. 1965. Die Bestimmung geringster Mengen Gesamtphosphor im Wasser von Binnenseen. Schweiz. Z. Hydrol. 27: 184-192.

SChrader, W., AND H. HeIN. 1983. ICP-AES-Analyse für Klärschlamm und Böden. Labor Praxis 7: 34.

SERruYa, C. 1977. Rates of sedimentation and resuspension in Lake Kinneret, p. 48-56. In Interactions between sediments and freshwater. Proc. Int. Symp. Junk.

Simola, H. 1981. Sedimentation in a eutrophic stratified lake in S. Finland. Ann. Bot. Fenn. 18: 2336.

SMITH, I. R. 1979. Hydraulic conditions in isothermal lakes. Freshwater Biol. 9: 119-145.

SMA: Schweiz. Meteorol. AnStalt. 1983a. Ergebnisse der täglichen Niederschlagsmessungen auf den Meteorologischen und Regenmess-Stationen der Schweiz.

. 1983b. Ann. Schweiz. Meteorol. Anstalt 119, 120.

TERwINDT, J. H. J. , 1977. Deposition, transportation and erosion of mud, p. 19-24. In Interactions between sediments and freshwater. Proc. Int. Symp. Junk.

VOGLER, P. 1965. Beiträge zur Phosphatanalytik in der Limnologie. 2. Die Bestimmung des gelösten Orthophosphates. Fortschr. Wasserchem. Grenzgeb. 2: 109-119. 